\title{
Nitro Derivatives of Naturally Occurring $\beta$-Asarone and Their Anticancer Activity
}

\author{
Suvarna Shenvi, ${ }^{1}$ Latha Diwakar, ${ }^{2}$ and G. Chandrasekara Reddy ${ }^{1}$ \\ ${ }^{1}$ Chemical Sciences Division, Vittal Mallya Scientific Research Foundation, BTM II Stage, Bangalore 560076, India \\ ${ }^{2}$ Department of Biological Sciences, Vittal Mallya Scientific Research Foundation, BTM II Stage, Bangalore 560076, India \\ Correspondence should be addressed to G. Chandrasekara Reddy; gcreddy@vmsrf.org
}

Received 21 July 2014; Accepted 15 September 2014; Published 1 October 2014

Academic Editor: Jochen Lehmann

Copyright (c) 2014 Suvarna Shenvi et al. This is an open access article distributed under the Creative Commons Attribution License, which permits unrestricted use, distribution, and reproduction in any medium, provided the original work is properly cited.

\begin{abstract}
$\beta$-Asarone (2, 4, 5-trimethoxy-(Z)-1-propenylbenzene) was obtained from Acorus calamus. Nitration of $\beta$-asarone with $\mathrm{AgNO}_{2} / \mathrm{I}_{2}$ in ether yielded 1-(2, 4, 5-trimethoxy phenyl)-2-nitropropene (1) but with $\mathrm{NaNO}_{2} / \mathrm{I}_{2}$ in ethylene glycol obtained 1-(2, 4, 5-trimethoxy phenyl)-1-nitropropene (2). Compound 2 was prepared for the first time and characterized using IR, ${ }^{1} \mathrm{H}-\mathrm{NMR}$, ${ }^{13} \mathrm{C}-\mathrm{NMR}$, and GC-MS spectra and it was converted into 1-(2, 4, 5-trimethoxy) phenyl-1-propanone (3) using modified Nef reaction. Based on 1D NOESY experiments, compounds $\mathbf{1}$ and $\mathbf{2}$ have been assigned $E$ configuration. Compounds $\mathbf{1}$ and $\mathbf{2}$ were subjected to cytotoxic activity using five human cancer cell lines, namely, MCF-7, SW-982, HeLa, PC-3, and IMR-32 by MTT assay. Except in breast cancer line (MCF-7) compound 2 exhibited five- to tenfold increase in activity compared to $\beta$-asarone and twofold increase over compound 1 .
\end{abstract}

\section{Introduction}

Acorus calamus (Acoraceae) also known as sweet flag in Indian traditional medicine is generally used for treatment of cough, fever, bronchitis, inflammation, depression, tumors, haemorrhoids, skin diseases, insomnia, hysteria, epilepsy, and loss of memory $[1,2]$. While $\beta$-asarone $(2$, 4, 5-trimethoxy-(Z)-1-propenylbenzene) was the main constituent (70 to $90 \%$ ) of rhizomes of Acorus calamus [3], $\alpha$-asarone (2, 4, 5-trimethoxy-(E)-1-propenylbenzene) was isolated as a minor component ( 8 to $14 \%$ ) from the rhizomes of related species Acorus gramineus [4]. Comparative study of genotoxicity and cytotoxicity of $\beta$-asarone and $\alpha$-asarone was investigated and found that $\alpha$-asarone was more toxic in the HepG2 cell system [5-7].

In continuation of our research on $\beta$-asarone, we carried out different chemical conversions to get pharmacologically active compounds $[8,9]$. Herein we report the preparation of nitro derivatives of $\beta$-asarone and their biological activity. Nitro group is an important functional group because it can be easily converted into many functional groups [1012]. Psychoactive drugs, namely, amphetamines, are generally prepared by reduction of $\beta$-methyl- $\beta$-nitrostyrenes [13-16]
Generally nitration of alkenes and substituted styrenes was carried out by metal nitrites using $\mathrm{NaNO}_{2} / \mathrm{AgNO}_{2}$ with iodine, $\mathrm{NaNO}_{2} / \mathrm{H}_{2} \mathrm{SO}_{4}$ in ether (Bruckner's method), $\mathrm{Cu}$ (II)tetrafluoroborate with $\mathrm{NaNO}_{2}$, alkyl halide and metal nitrite (Victor-Meyer reaction), and $\mathrm{HgCl}_{2}-\mathrm{NaNO}_{2}$ [17-23] . Formation of nitryl iodide was first reported by Birchenbachin 1932 from $\mathrm{AgNO}_{2} / \mathrm{I}_{2}$ [24]. Later on $\mathrm{AgNO}_{2}$ was replaced with less expensive $\mathrm{NaNO}_{2} / \mathrm{H}_{2} \mathrm{O} / \mathrm{I}_{2} /$ EtOAc/ethylene glycol or $\mathrm{KNO}_{2} / 18$-crown-6/I $/ 2$ THF [25-27].

\section{Results and Discussion}

2.1. Chemistry. Naturally occurring $\beta$-asarone when subjected to nitration with nitryl iodide $\left(\mathrm{NaNO}_{2} / \mathrm{I}_{2}\right.$ /ethylene glycol) obtained 1-(2, 4, 5-trimethoxy phenyl)-1-nitropropene (2) (Scheme 1) as yellow crystals. It showed a molecular ion peak at $253\left(\mathrm{M}^{+}\right)$corresponding to the molecular formula $\mathrm{C}_{12} \mathrm{H}_{15} \mathrm{NO}_{5}$. In ${ }^{1} \mathrm{H}$-NMR spectrum methyl group appeared as a doublet at $\delta_{H} 1.80(J=7.6 \mathrm{~Hz})$ with vinylic proton appearing as a quartet at $\delta_{H} 7.40(J=14.6$ and $7.6 \mathrm{~Hz})$ indicating that vinylic proton is adjacent to methyl group. When the methyl peak in PMR at $\delta 1.80$ was irradiated, enhancement of peaks 


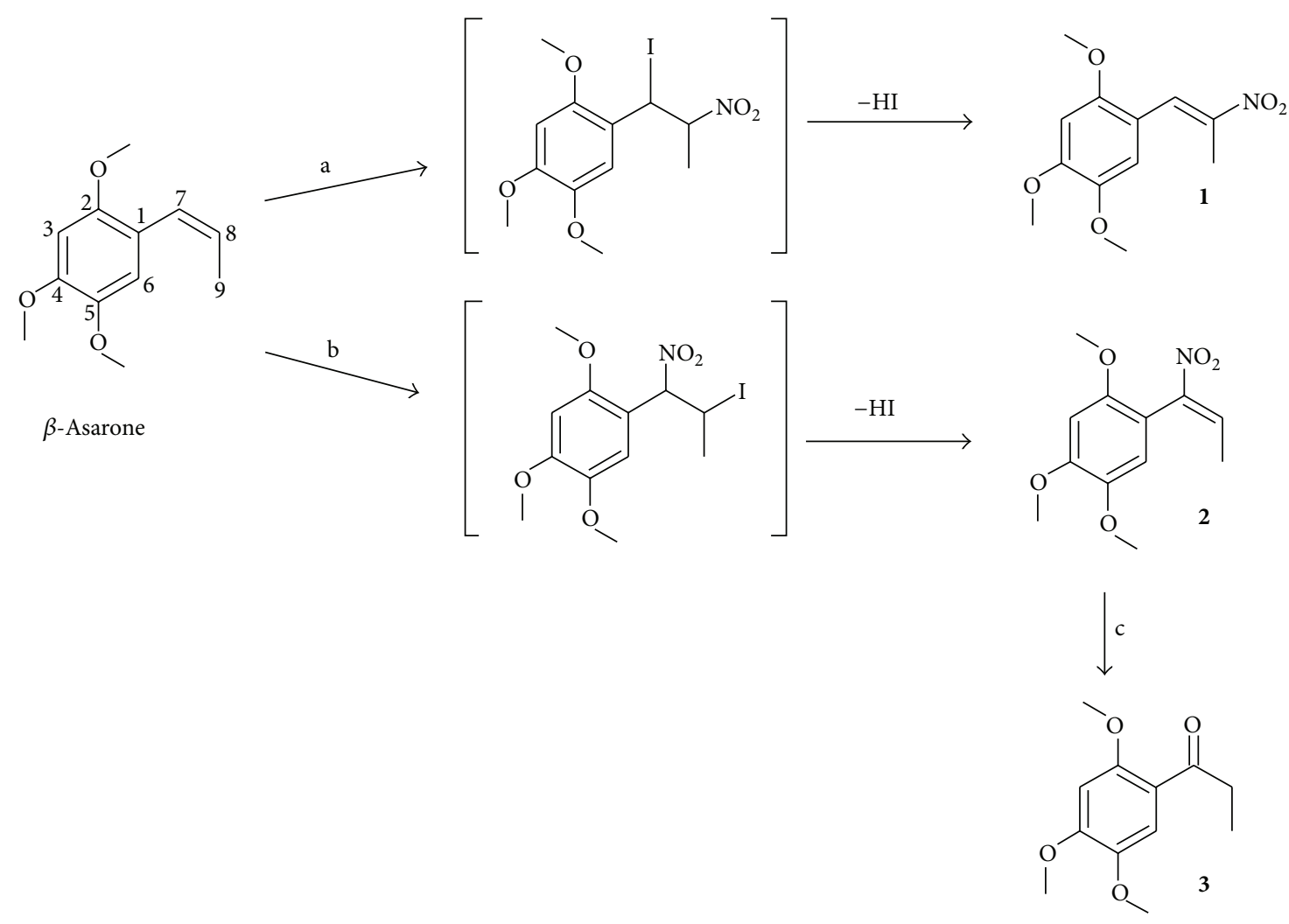

Scheme 1: Synthesis of 1-(2, 4, 5-trimethoxy phenyl)-2-nitropropene (1), 1-(2, 4, 5-trimethoxy phenyl)-1-nitropropene (2), and 1-(2, 4, 5trimethoxy)phenyl-1-propanone (3). Reagents and Conditions. (a) $\mathrm{AgNO}_{2}, \mathrm{I}_{2}$, ether, room temperature $30 \mathrm{~h}$; (b) $\mathrm{NaNO}_{2}, \mathrm{I}_{2}$, ethylene glycol, room temperature $48 \mathrm{~h}$; (c) $\mathrm{NaBH}_{4}, \mathrm{MeOH}$, room temperature $30 \mathrm{~min}$.

at $\delta 6.67$ and $\delta 7.40$ corresponding to $\mathrm{H}-6$ and vinylic proton was observed indicating that compound 2 is indeed 1-(2, 4, 5-trimethoxy phenyl)-(E)-1-nitropropene. The formation of compound $\mathbf{2}$ is quite unique and there was no report of formation of this earlier. Further proof that compound 2 is 1-nitropropenyl derivative has come from the fact that when it was subjected to modified Nef reaction using sodium borohydride (wherein $\alpha, \beta$-unsaturated nitroalkenes yield corresponding ketones by hydrolysis of the corresponding nitronates $[28,29]$, it gave 1-(2, 4, 5-trimethoxy)phenyl-1propanone (3, isoacoromone)) [3]. Sy and By reported that nitration of substituted styrenes with nitryl iodide regioselectively yielded $\beta$-nitrostyrenes (2-nitropropenyl derivatives) and not $\alpha$-nitrostyrenes (1-nitropropenyl derivative) [24]. We have also prepared 1-(2, 4, 5-trimethoxy phenyl)-2nitropropene (1) by the nitration of $\beta$-asarone with $\mathrm{AgNO}_{2} / \mathrm{I}_{2}$ in ether and characterized it by recording its PMR spectrum. When the methyl peak in PMR at $\delta 2.42$ of compound 1 was irradiated, no enhancement of any other peaks was observed. The formation of compound 1 was confirmed by synthesizing the molecule through the condensation of 2, 4, 5-trimethoxy benzaldehyde with nitroethane $[30,31]$. It is clear from these experiments that formation of nitro derivatives of $\beta$-asarone depends on the solvent used during nitration.

2.2. Biological Activity. Compounds $\mathbf{1}$ and $\mathbf{2}$ were screened for their anticancer activity against five human cancer cell lines by MTT assay (Table 1) with the naturally occurring $\beta$-asarone and camptothecin taken as standards. Except in breast cancer cell line (MCF-7), compound 2 exhibited fiveto tenfold increase in activity compared to $\beta$-asarone and twofold increase over compound $\mathbf{1}$.

2.2.1. Anticancer Assay. Cell lines were maintained in Dulbecco's Modified Eagle's Medium (Sigma-Aldrich Inc., USA) supplemented with $10 \%$ fetal bovine serum (Gibco BRL., USA) in a $\mathrm{CO}_{2}$ incubator at $37^{\circ} \mathrm{C}$. The cytotoxicity of the compounds was measured by MTT assay [32]. Five different kinds of human cancer cell lines, namely, HeLa (cervical), MCF-7 (breast), SW-982 (synovial), PC-3 (prostate cancer), and IMR-32 (neuroblastoma), were plated in a 96-well plate at the density of 10,000 cells per well. After $24 \mathrm{~h}$, cells were treated with various concentrations of compounds from $200 \mu \mathrm{M}$ serially diluted up to $1.56 \mu \mathrm{M}$ using camptothecin as standard. The cells were further incubated for $48 \mathrm{~h}$, and $20 \mu \mathrm{L}$ of MTT ( $5 \mathrm{mg} / \mathrm{mL}$ stock, Sigma-Aldrich Inc., USA) was added to each well and incubated for another three hours. The purple formazan crystals formed were dissolved by adding $100 \mu \mathrm{L}$ of DMSO to each well and absorbance was read at $570 \mathrm{~nm}$ in a spectrophotometer [SpectraMax 340]. The cell death was calculated as follows:

$$
\text { Cell death }=100-\left[\left(\frac{\text { test absorbance }}{\text { control absorbance }}\right) \times 100\right] \text {. }
$$


TABLE 1: Cytotoxic activity for nitro derivatives of $\beta$-asarone by MTT assay.

\begin{tabular}{|c|c|c|c|c|c|}
\hline \multicolumn{6}{|c|}{$\mathrm{IC}_{50}$ values $(\mu \mathrm{M})^{\mathrm{a}}$} \\
\hline Compounds & $\mathrm{HeLa}^{\mathrm{b}}$ & MCF-7 ${ }^{\mathrm{c}}$ & SW- $-982^{\mathrm{d}}$ & $\mathrm{PC}-3^{\mathrm{e}}$ & IMR-32 ${ }^{\mathrm{f}}$ \\
\hline 1 & $39.24 \pm 4.40$ & $73.65 \pm 3.26$ & $42.65 \pm 11.42$ & $30.05 \pm 6.13$ & $47.14 \pm 8.43$ \\
\hline 2 & $25.03 \pm 4.32$ & $74.28 \pm 6.28$ & $11.84 \pm 3.23$ & $25.44 \pm 6.76$ & $18.10 \pm 2.14$ \\
\hline$\beta$-Asarone & $126.11 \pm 6.82$ & $>150$ & $129.35 \pm 8.12$ & $>150$ & $>150$ \\
\hline Camptothecin & $3.09 \pm 0.34$ & $27.34 \pm 9.89$ & $9.15 \pm 0.36$ & $3.42 \pm 0.35$ & $5.07 \pm 1.32$ \\
\hline
\end{tabular}

${ }^{\mathrm{a}} \mathrm{IC}_{50}$ : each set of data represents mean \pm S.D from three different test results in triplicate and is expressed as the concentration of test compound which inhibits the cell growth by $50 \%$.

${ }^{b}$ HeLa: human cervical cancer; ${ }^{c}$ MCF-7: human breast cancer; ${ }^{d}$ SW-982: human synovial sarcoma; ${ }^{e}$ PC-3: human prostate cancer; ${ }^{\mathrm{f}}$ IMR-132: human neuroblastoma.

The cytotoxic activity of compounds was expressed as the concentration in $\mu \mathrm{M}$ at which they inhibit the cell growth by $50 \%\left(\mathrm{IC}_{50}\right)$.

\section{Experimental}

3.1. Chemistry. All chemicals were purchased from Laboratory Reagent (LR) grade. Fresh rhizome of Acorus calamus was collected from marshy areas of Kunigal in Karnataka, India in 2012. Melting points were recorded on an Acro melting point apparatus using a calibrated thermometer. Thin layer chromatography (TLC) and column chromatography (CC) were performed with [TLC silica gel $60 \mathrm{~F}_{254}$. Merck] and silica gel (Kieselgel 60, 230-400 mesh, Merck), respectively. Chromatograms were developed using hexane-EtOAc $(8: 2$, v/v). IR spectra were recorded on Thermo-Nicolet instrument in $\mathrm{KBr}$ discs. Mass spectra were recorded using GCMSQP2010S (direct probe). PMR spectra and ${ }^{13} \mathrm{C}$ NMR spectra were recorded in $\mathrm{CDCl}_{3}$ with TMS (tetramethylsilane) as an internal standard on a Bruker AG spectrometer and chemical shifts were recorded in $\delta$ units.

3.2. 3-(2, 4, 5-Trimethoxy-(Z)-1-propenyl benzene). IR ( $\mathrm{KBr})$ : $3421,2939,1589,1512,1469,1211,1145,1029,833 \mathrm{~cm}^{-1}$.

${ }^{1} \mathrm{H} \mathrm{NMR}\left(\mathrm{CDCl}_{3}, 200 \mathrm{MHz}\right): \delta 1.88(3 \mathrm{H}, \mathrm{dd}, J=2.0$, $\left.7.0 \mathrm{~Hz}, \mathrm{CH}_{3}\right), 3.81\left(3 \mathrm{H}, \mathrm{s}, \mathrm{OCH}_{3}\right), 3.84\left(3 \mathrm{H}, \mathrm{s}, \mathrm{OCH}_{3}\right), 3.90$ $\left(3 \mathrm{H}, \mathrm{s}, \mathrm{OCH}_{3}\right), 5.78(1 \mathrm{H}, \mathrm{m}, \mathrm{H}-8), 6.49(1 \mathrm{H}, \mathrm{m}, \mathrm{H}-7), 6.53(1 \mathrm{H}$, s, H-3), 6.84 (1H, s, H-6).

${ }^{13} \mathrm{C} \mathrm{NMR}\left(\mathrm{CDCl}_{3}, 50 \mathrm{MHz}\right): \delta 153.58,150.58,143.26$, $126.74,126.42,119.32,116.71,97.28,56.98\left(\mathrm{OCH}_{3}\right), 56.53$ $\left(\mathrm{OCH}_{3}\right), 56.38\left(\mathrm{OCH}_{3}\right), 14.78(\mathrm{C}-9)$.

GC-MS $(m / z)=208[\mathrm{M}]^{+}(25), 193(10), 165(15), 150(5)$, 135 (12), 119 (5), 105 (5), 91 (14).

3.3. 1-(2, 4, 5-Trimethoxy phenyl)-2-nitropropene (1). Iodine (1016 mg, $4 \mathrm{mmol}$ ) and $\mathrm{AgNO}_{2}$ (616 mg, $4 \mathrm{mmol}$ ) were stirred in anhydrous ether $(20 \mathrm{~mL})$ at room temperature under nitrogen for $45 \mathrm{~min}$. $\beta$-Asarone $(236 \mathrm{mg}, 2 \mathrm{mmol}$ ) and pyridine $(632 \mathrm{mg}, 8 \mathrm{mmol})$ in ether were added and the mixture was stirred at room temperature for $30 \mathrm{~h}$ as per the reported procedure [24]. The dark brown liquid material obtained was chromatographed on silica and eluted with hexane/ethyl acetate to give pure product $\mathbf{1}$ which was crystallized from methanol (1-(2, 4, 5-trimethoxy phenyl)2-nitropropene exists in two modifications, yellow and red prisms, and depending on concentration and precipitation speed, one often gets a mixture of both species. Yellow crystal melts at $98-100^{\circ} \mathrm{C}$ and dark orange (red) crystal melts at 99$101^{\circ} \mathrm{C}$. The red form transforms itself to the yellow form at $\left.90^{\circ} \mathrm{C}\right)(238 \mathrm{mg}, 73.2 \%)$.

IR (KBr): 2945, 1612, 1509, 1490, 1335, 1278, 1216, $1136 \mathrm{~cm}^{-1}$.

${ }^{1} \mathrm{H}$ NMR $\left(\mathrm{CDCl}_{3}, 400 \mathrm{MHz}\right): \delta 2.42(3 \mathrm{H}, \mathrm{s}, \mathrm{H}-9), 3.85$ $\left(3 \mathrm{H}, \mathrm{s}, \mathrm{OCH}_{3}\right), 3.87\left(3 \mathrm{H}, \mathrm{s}, \mathrm{OCH}_{3}\right), 3.94\left(3 \mathrm{H}, \mathrm{s}, \mathrm{OCH}_{3}\right), 6.54$ (1H, s, H-3), 6.87 (1H, s, H-6), 8.30 (1H, s H-7).

${ }^{13} \mathrm{C} \mathrm{NMR}\left(\mathrm{CDCl}_{3}, 100 \mathrm{MHz}\right): \delta 153.58,152.44,145.58$, $142.26,128.74,133.01,111.64,97.28,56.78\left(\mathrm{OCH}_{3}\right), 56.53$ $\left(\mathrm{OCH}_{3}\right), 56.05\left(\mathrm{OCH}_{3}\right), 14.58\left(\mathrm{CH}_{3}\right)$.

GC-MS $(m / z)=253\left[\mathrm{M}^{+} \cdot\right](42), 207$ (100), 192 (70), 177 (62), 161 (28), 149 (25), 131 (12), 121 (30), 107 (12).

3.4. Synthesis of 1 . To a solution of 2, 4, 5-trimethoxy benzaldehyde (7.6 g, $38.7 \mathrm{mmol})$ in nitroethane $(27 \mathrm{~g}, 386 \mathrm{mmol})$ was added ammonium acetate $(1.7 \mathrm{~g}, 22.0 \mathrm{mmol})$ and the reaction mixture heated to $75-80^{\circ} \mathrm{C}$ for $3 \mathrm{hrs}$. After completion of the reaction, nitroethane was removed under vacuum, and oily orange mass was triturated with hot methanol $(3 \times$ $50 \mathrm{~mL}$ ). Methanol extract was concentrated and allowed to stand at room temperature. Yellow crystals (75-78\% yield) were obtained having the melting point $98-100^{\circ} \mathrm{C} .1-(2,4$, 5 -Trimethoxy phenyl)-2-nitropropene obtained by nitration of $\beta$-asarone using $\mathrm{AgNO}_{2} / \mathrm{I}_{2}$ /ether was identical with this synthetic compound on TLC, $\mathrm{mp}$, and $\mathrm{mmp}$.

3.5. 1-(2, 4, 5-Trimethoxy phenyl)-1-nitropropene (2). A mixture of $\beta$-asarone $(10 \mathrm{~g}, 48 \mathrm{mmol})$ in $150 \mathrm{~mL}$ of ethyl acetate containing iodine $(18.28 \mathrm{~g}, 72 \mathrm{mmol})$ at $0^{\circ} \mathrm{C}$ was added to a solution of sodium nitrite (13.24 g, $192 \mathrm{mmol})$, ethylene glycol $(8.93 \mathrm{~g}, 144 \mathrm{mmol})$, and water $20 \mathrm{~mL}$. The reaction mixture was stirred at room temperature for $48 \mathrm{hrs}$ under nitrogen and the ethyl acetate layer was separated, washed with water and then with $10 \%$ thiosulphate, and dried over $\mathrm{MgSO}_{4}$. Ethyl acetate layer was evaporated and recrystallized from methanol to obtain a yellow crystalline compound (70-75\% yield).

MP: $158-160^{\circ} \mathrm{C}$.

IR (KBr): 2948, 1645, 1346, 1214, 1032, 829, $769 \mathrm{~cm}^{-1}$. 
${ }^{1} \mathrm{H}$ NMR $\left(\mathrm{CDCl}_{3}, 400 \mathrm{MHz}\right): \delta 1.80(3 \mathrm{H}, \mathrm{d}, J=7.6 \mathrm{~Hz}$, $\left.\mathrm{CH}_{3}\right), 3.76\left(3 \mathrm{H}, \mathrm{s}, \mathrm{OCH}_{3}\right), 3.83\left(3 \mathrm{H}, \mathrm{s}, \mathrm{OCH}_{3}\right), 3.93(3 \mathrm{H}, \mathrm{s}$, $\left.\mathrm{OCH}_{3}\right), 6.57(1 \mathrm{H}, \mathrm{s}, \mathrm{H}-3), 6.67(1 \mathrm{H}, \mathrm{s}, \mathrm{H}-6), 7.40(1 \mathrm{H}, \mathrm{q}, J=$ 14.6 and $7.6 \mathrm{~Hz}, \mathrm{H}-8)$.

${ }^{13} \mathrm{C} \mathrm{NMR}\left(\mathrm{CDCl}_{3}, 100 \mathrm{MHz}\right): \delta 152.64,151.44,149.58$, $142.86,133.74,115.01,109.64,97.28,56.73\left(\mathrm{OCH}_{3}\right), 56.33$ $\left(\mathrm{OCH}_{3}\right), 56.05\left(\mathrm{OCH}_{3}\right), 14.28\left(\mathrm{CH}_{3}\right)$.

GC-MS $(m / z)=253\left[\mathrm{M}^{+} \cdot\right](74), 207(100), 192(40), 177$ (55), 161 (26), 149 (24), 131 (12), 121 (32).

3.6. 1-(2, 4, 5-Trimethoxy)phenyl-1-propanone (3). To a solution of compound $2(1 \mathrm{~g}, 4.46 \mathrm{mmol})$ in methanol $(25 \mathrm{~mL})$ was added sodium borohydride $(0.5 \mathrm{~g}, 3.2 \mathrm{mmol})$ and stirred the reaction mixture at $25-30^{\circ} \mathrm{C}$ for 30 minutes. Completion of the reaction was confirmed by TLC. The reaction mixture was concentrated under vacuum and acidified with dilHCl to $\mathrm{pH}$ about 4.0 and extracted with $\mathrm{CH}_{2} \mathrm{Cl}_{2}(2 \times 15 \mathrm{~mL})$ washed with water and dried over $\mathrm{Na}_{2} \mathrm{SO}_{4}$. Evaporation of $\mathrm{CH}_{2} \mathrm{Cl}_{2}$ layer followed by crystallization from methanol gave colourless crystals.

MP: $108-109^{\circ} \mathrm{C}$.

IR (KBr): 2959, 1712, 1649, 1618, 1510, 1215, 1028, 810, $750 \mathrm{~cm}^{-1}$.

${ }^{1} \mathrm{H}$ NMR $\left(\mathrm{CDCl}_{3}, 200 \mathrm{MHz}\right): \delta 1.18(3 \mathrm{H}, \mathrm{t}, J=7.2 \mathrm{~Hz}$, $\left.\mathrm{CH}_{3}\right), 2.99\left(2 \mathrm{H}, \mathrm{q}, J=14.5 \& 7.2 \mathrm{~Hz}, \mathrm{CH}_{2}\right), 3.85(3 \mathrm{H}, \mathrm{s}$, $\left.\mathrm{OCH}_{3}\right), 3.87\left(3 \mathrm{H}, \mathrm{s}, \mathrm{OCH}_{3}\right), 3.91\left(3 \mathrm{H}, \mathrm{s}, \mathrm{OCH}_{3}\right), 6.50(1 \mathrm{H}$, s, H-3), 7.43 (1H, s, H-6).

${ }^{13} \mathrm{C} \mathrm{NMR}\left(\mathrm{CDCl}_{3}, 50 \mathrm{MHz}\right): \delta 200.73(\mathrm{C}=\mathrm{O}), 155.16$, $153.58,143.09,119.19,112.80,96.56,56.28\left(\mathrm{OCH}_{3}\right), 56.18$ $\left(\mathrm{OCH}_{3}\right), 56.10\left(\mathrm{OCH}_{3}\right), 37.07\left(\mathrm{CH}_{2}\right), 8.63\left(\mathrm{CH}_{3}\right)$.

GC-MS $(m / z)=224\left[\mathrm{M}^{+\cdot}\right](38), 195$ (100), 180 (10), 165 (5), 151 (10), 137 (12), 122 (32), 109 (5).

\section{Conclusions}

$\beta$-Asarone (2, 4, 5-trimethoxy-(Z)-1-propenylbenzene) when subjected to nitration gave $1-(2,4,5$-trimethoxy phenyl)2-nitropropene (1) and 1-(2, 4, 5-trimethoxy phenyl)-1nitropropene (2). Preparation of compound $\mathbf{2}$ is reported here for the first time. The cytotoxic activities of these nitro derivatives were compared with $\beta$-asarone in five human cancer cell lines namely MCF-7, SW-982, HeLa, PC-3 and IMR-32 using MTT assay. Except in breast cancer line (MCF-7) compound 2 exhibited five- to tenfold increase in activity compared to $\beta$-asarone and twofold increase over compound $\mathbf{1}$.

\section{Conflict of Interests}

The authors declare that there is no conflict of interests regarding the publication of this paper.

\section{Acknowledgments}

The authors express sincere thanks to Dr. Anil Kush, CEO of Vittal Mallya Scientific Research Foundation, for his keen interest and encouragement, to DBT, Government of India, for the financial support (Grant no. BT/PR11756/
AGR/05/456/2009t), and Mr. A. C. Karunakara and Mr. K. Rijesh for technical assistance. Their thanks are due to NMR Research facilities, I. I. Sc., Bangalore, for recording the spectra.

\section{References}

[1] S. R. Yende, U. N. Harle, D. T. Rajgure, T. A. Tuse, and N. S. Vyawahare, "Pharmacological profile of Acorus calamus: an overview," Pharmacognosy Reviews, vol. 2, no. 4, pp. 22-26, 2008.

[2] A. E. Raja, M. Vijayalakshmi, and G. Devalarao, "Acorus calamus linn.: chemistry and biology," Research Journal of Pharmacy and Technology, vol. 2, pp. 256-261, 2009.

[3] A. K. Sinha, B. P. Joshi, and R. Acharya, "Process for the preparation of pharmacologically active $\alpha$-asarone from toxic $\beta$-asarone rich acorus calamus oil," US Patent US6590127 B1, 2003.

[4] J. Y. Lee, B.-S. Yun, and B. K. Hwang, "Antifungal Activity of $\beta$-Asarone from Rhizomes of Acorus gramineus," Journal of Agricultural and Food Chemistry, vol. 52, no. 4, pp. 776-780, 2004.

[5] D.-J. Zou, G. Wang, J.-C. Liu et al., "Beta-asarone attenuates beta-amyloid-induced apoptosis through the inhibition of the activation of apoptosis signal-regulating kinase 1 in SH-SY5Y cells," Pharmazie, vol. 66, no. 1, pp. 44-51, 2011.

[6] P. Unger and M. F. Melzig, "Comparative study of the cytotoxicity and genotoxicity of alpha- and beta-asarone," Scientia Pharmaceutica, vol. 80, no. 3, pp. 663-668, 2012.

[7] X. Zou, S.-L. Liu, J.-Y. Zhou, J. Wu, B.-F. Ling, and R.-P. Wang, "Beta-asarone induces LoVo colon cancer cell apoptosis by upregulation of caspases through a mitochondrial pathway in vitro and in vivo," Asian Pacific Journal of Cancer Prevention, vol. 13, no. 10, pp. 5291-5298, 2012.

[8] S. Shenvi, K. Kumar, K. S. Hatti, K. Rijesh, L. Diwakar, and G. C. Reddy, "Synthesis, anticancer and antioxidant activities of 2,4,5trimethoxy chalcones and analogues from asaronaldehyde: Structure-activity relationship," European Journal of Medicinal Chemistry, vol. 62, pp. 435-442, 2013.

[9] S. Shenvi, Vinod, R. Hegde, A. Kush, and G. C. Reddy, "A unique water soluble formulation of $\beta$-asarone from sweet flag (Acorus calamus L.) and its in vitro activity against some fungal plant pathogens," Journal of Medicinal Plant Research, vol. 5, no. 20, pp. 5132-5137, 2011.

[10] E. J. Corey and H. Estreicher, "A new synthesis of conjugated nitro cyclo olefins, unusually versatile synthetic intermediates," Journal of the American Chemical Society, vol. 100, no. 19, pp. 6294-6295, 1978.

[11] P. K. Pradhan, S. Dey, P. Jaisankar, and V. S. Giri, "Fe-HCl: an efficient reagent for deprotection of oximes as well as selective oxidative hydrolysis of nitroalkenes and nitroalkanes to ketones," Synthetic Communications, vol. 35, no. 7, pp. 913922, 2005.

[12] R. Ballini, L. Barboni, F. Fringuelli, A. Palmieri, F. Pizzo, and L. Vaccaro, "Recent developments on the chemistry of aliphatic nitro compounds under aqueous medium," Green Chemistry, vol. 9, no. 8, pp. 823-838, 2007.

[13] D. G. Musson, D. Karashima, H. Rubiero, K. L. Melmon, A. Cheng, and N. Castagnoli Jr., "Synthetic and preliminary hemodynamic and whole animal toxicity studies on (R,S)-, (R), and (S)-2-methyl-3-(2,4,5-trihydroxyphenyl)alanine," Journal of Medicinal Chemistry, vol. 23, no. 12, pp. 1318-1323, 1980. 
[14] N. Milhazes, T. Cunha-Oliveira, P. Martins et al., "Synthesis and cytotoxic profile of 3,4-methylenedioxymethamphetamine ("ecstasy") and its metabolites on undifferentiated PC12 cells: a putative structure-toxicity relationship," Chemical Research in Toxicology, vol. 19, no. 10, pp. 1294-1304, 2006.

[15] S. Freeman and J. F. Alder, "Arylethylamine psychotropic recreational drugs: a chemical perspective," European Journal of Medicinal Chemistry, vol. 37, no. 7, pp. 527-539, 2002.

[16] A. T. Shulgin, "The six trimethoxyphenylisopropylamines (trimethoxyamphetamines)," Journal of Medicinal Chemistry, vol. 9, no. 3, pp. 445-446, 1966.

[17] A. J. Kresge, "The nitroalkene anomaly," Canadian Journal of Chemistry, vol. 52, no. 10, pp. 1897-1903, 1974.

[18] S. E. Denmark and L. R. Marcin, "A general method for the preparation of 2,2-disubstituted 1-nitroalkenes," Journal of Organic Chemistry, vol. 58, no. 15, pp. 3850-3856, 1993.

[19] G. W. Kabalka and R. S. Varma, "Syntheses and selected reductions of conjugated nitroalkenes. A review," Organic Preparations and Procedures International, vol. 19, pp. 283-328, 1987.

[20] A. Hassner, J. E. Kropp, and G. J. Kent, "Addition of nitryl iodide to olefins," Journal of Organic Chemistry, vol. 34, no. 9, pp. 26282632, 1969.

[21] P. J. Campos, B. García, and M. Á. Rodríguez, "One-pot selective synthesis of $\beta$-nitrostyrenes from styrenes, promoted by Cu(II)," Tetrahedron Letters, vol. 41, no. 6, pp. 979-982, 2000.

[22] D. E. Bergbreiter and J. J. Lalonde, "Michael additions of nitroalkanes to $\alpha, \beta$-unsaturated carbonyl compounds using $\mathrm{KF} /$ basic alumina," Journal of Organic Chemistry, vol. 52, no. 8, pp. 16011603, 1987.

[23] S. S. Jew, H. D. Kim, Y. S. Cho, and C. H. Cook, "A practical preparation of conjugated nitroalkenes," Chemical Letters, vol. 10, pp. 1747-1748, 1986.

[24] W.-W. Sy and A. W. By, "Nitration of substituted styrenes with nitryl iodide," Tetrahedron Letters, vol. 26, no. 9, pp. 1193-1196, 1985.

[25] V. Bruckner, "Ueber die Verwendung der Pseudo-nitrosite II," Journal für Praktische Chemie, vol. 148, pp. 117-125, 1937.

[26] D. Ghosh and D. E. Nichols, "An improved method for the preparation of nitroalkenes from alkenes," Synthesis, vol. 2, pp. 195-197, 1996.

[27] R. Ballini, L. Barboni, and G. Giarlo, "The first conversion of primary alkyl halides to nitroalkanes under aqueous medium," Journal of Organic Chemistry, vol. 69, no. 20, pp. 6907-6908, 2004.

[28] M. S. Mourad, R. S. Varma, and G. W. Kabalka, "Reduction of $\alpha, \beta$-unsaturated nitroalkenes with trialkylborohydrides; a synthesis of ketones," Synthesis, vol. 1985, no. 6-7, pp. 654-656, 1985.

[29] R. Ballini and M. Petrini, "Recent synthetic developments in the nitro to carbonyl conversion (Nef reaction)," Tetrahedron, vol. 60, no. 5, pp. 1017-1047, 2004.

[30] B. T. Ho, L. W. Tansey, R. L. Balster, R. An, W. M. McIsaac, and R. T. Harris, "Amphetamine analogs. II. Methylated phenethylamines," Journal of Medicinal Chemistry, vol. 13, no. 1, pp. 134135, 1970.

[31] Uemura, "2,4,5-Trimethoxyphenyl-2-nitropropene: an alternative approach," Rhodium Archive, 2004.

[32] T. Mosmann, "Rapid colorimetric assay for cellular growth and survival: application to proliferation and cytotoxicity assays," Journal of Immunological Methods, vol. 65, no. 1-2, pp. 55-63, 1983. 

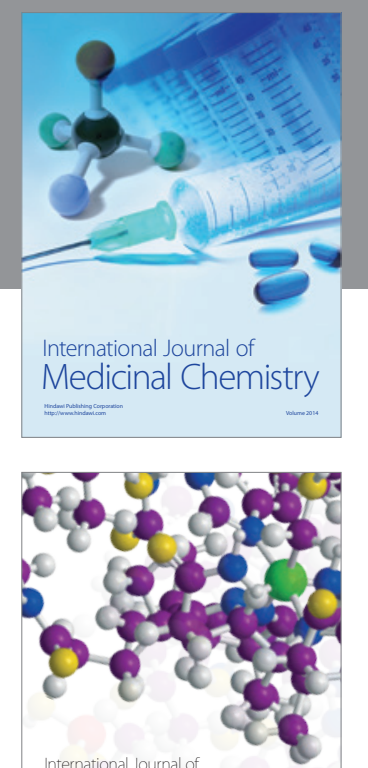

\section{Carbohydrate} Chemistry

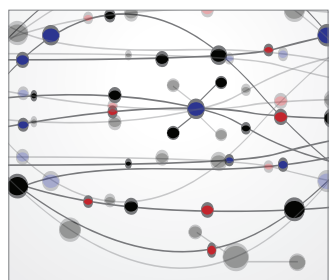

The Scientific World Journal
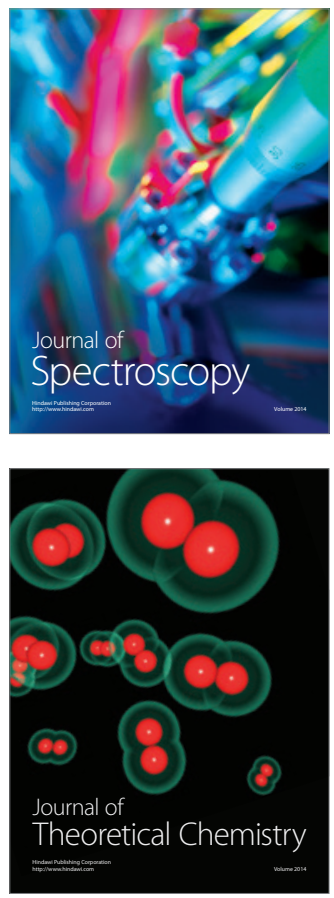
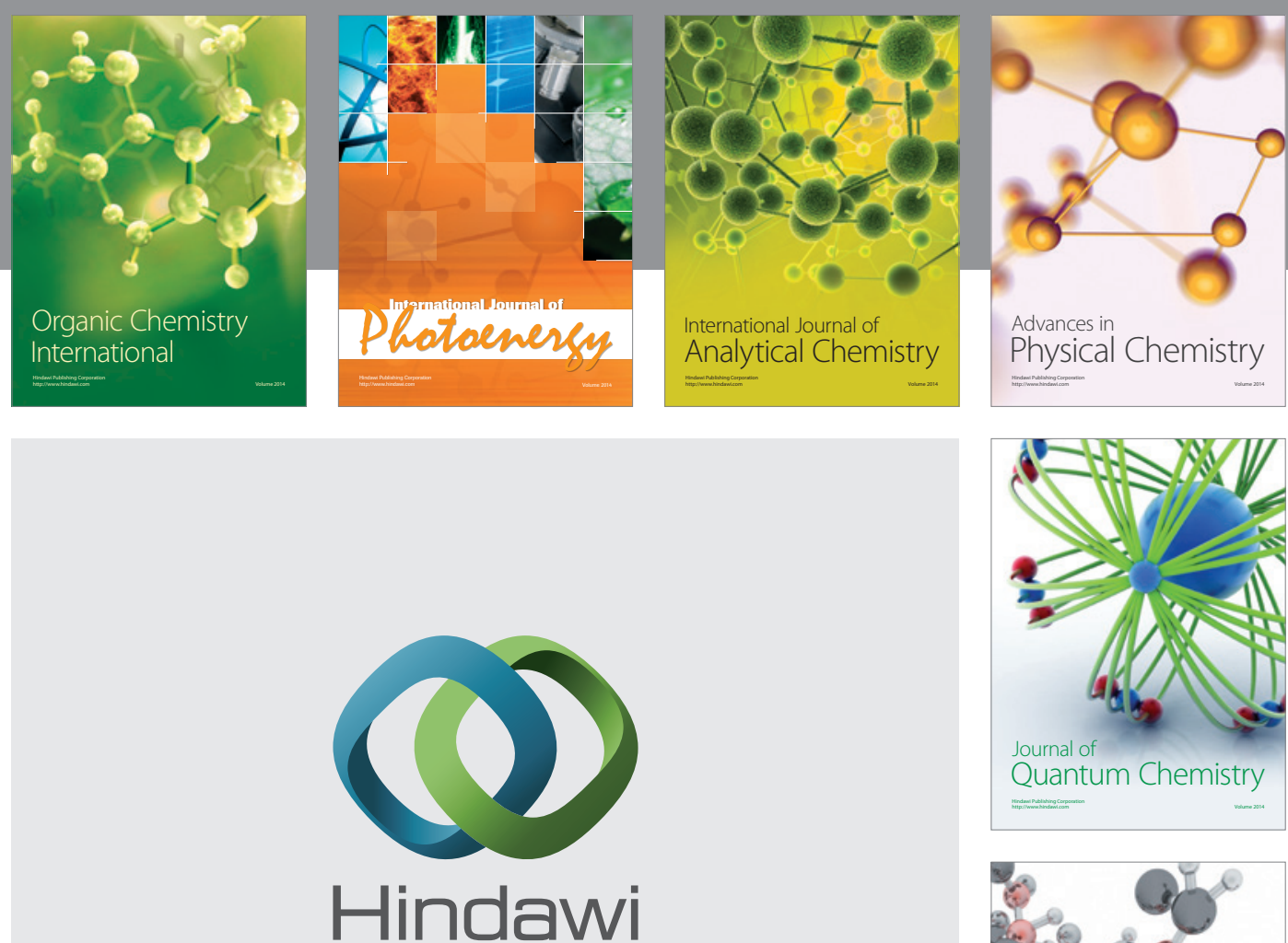

Submit your manuscripts at

http://www.hindawi.com

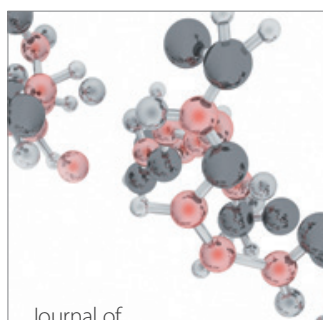

Analytical Methods

in Chemistry

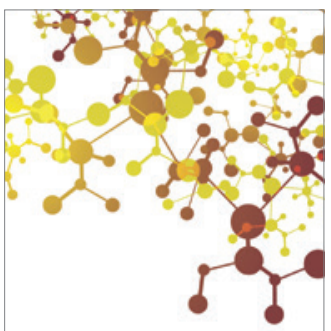

Journal of

Applied Chemistry

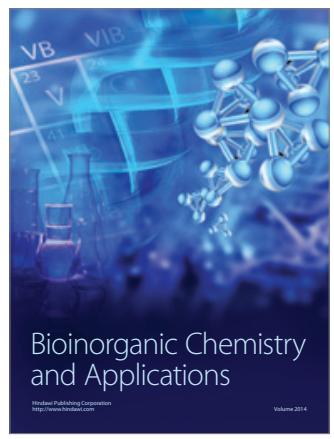

Inorganic Chemistry
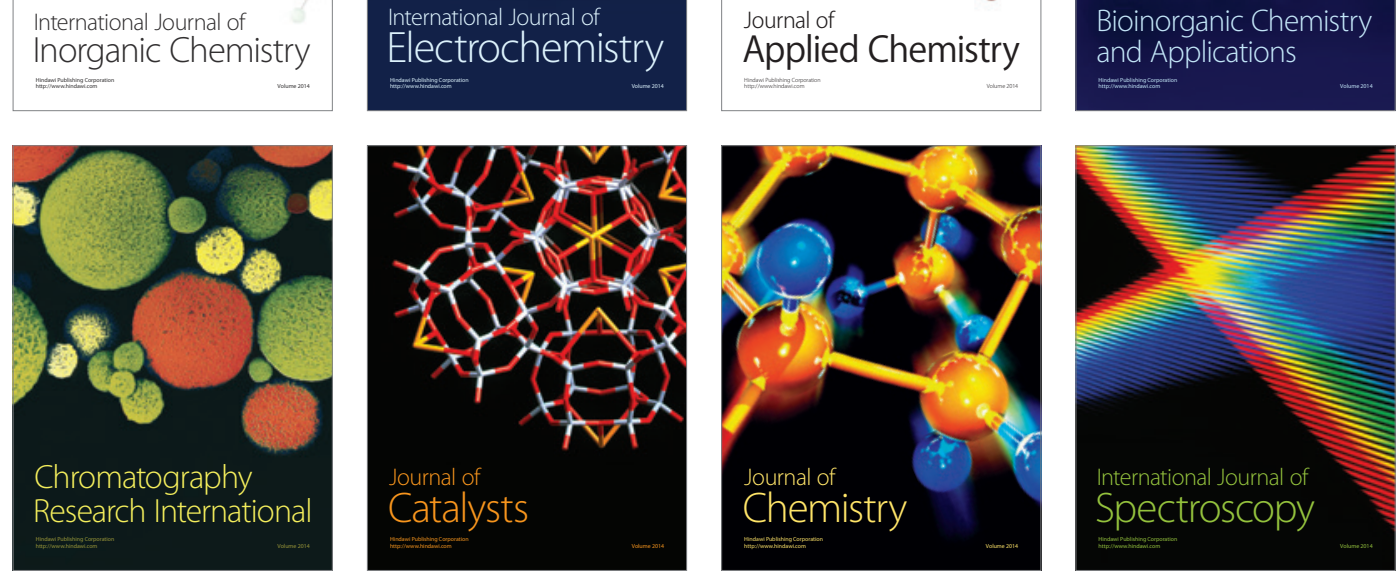